\title{
PENINGKATAN KEMAMPUAN KOMUNIKASI MATEMATIS SISWA KELAS VII-1 SMP LABORATORIUM UNDIKSHA MELALUI PENERAPAN MODEL PEMBELAJARAN PROCESS ORIENTED GUIDED INQUIRY LEARNING
}

\author{
N. L. H. Purnamayanti, I. P. W. Ariawan, I. P. P. Suryawan \\ Jurusan Pendidikan Matematika Universitas Pendidikan Ganesha \\ Singaraja, Indonesia \\ e-mail: henipurnama100@gmail.com,wisnab36@gmail.com \\ pasek.suryawan@yahoo.co.id
}

\begin{abstract}
Abstrak
Penelitian ini bertujuan untuk mengetahui: (1) penerapan model pembelajaran process oriented guided inquiry learning (POGIL) untuk meningkatkan kemampuan komunikasi matematis siswa dan (2) tanggapan siswa terhadap penerapan model pembelajaran POGIL. Jenis penelitian ini adalah penelitian tindakan kelas yang dilaksanakan dalam tiga siklus. Subjek penelitian ini adalah siswa kelas VII-1 SMP Laboratorium Undiksha sebanyak 26 siswa pada semester genap tahun ajaran 2017/2018. Data komunikasi matematis siswa dikumpulkan menggunakan tes komunikasi matematis dan tanggapan siswa dikumpulkan menggunakan angket. Data yang telah terkumpul selanjutnya dianalisis secara deskriptif. Hasil penelitian menunjukkan bahwa komunikasi matematis siswa mengalami peningkatan rata-rata nilai dari 43,59 pada refleksi awal terus meningkat dari siklus ke siklus menjadi 83,33 pada siklus III dari nilai maksimal 100. Ketuntasan belajar siswa juga mengalami peningkatan dari $7,69 \%$ pada refleksi awal menjadi $84,62 \%$ pada siklus III. Rata-rata skor tanggapan siswa telah berada dalam kategori positif. Peningkatan pada setiap siklus terjadi karena guru lebih menekankan pada: (1) penggalian informasi secara aktif oleh siswa dengan menyelesaikan permasalahan pada kegiatan eksplorasi, (2) menganalisa informasi yang telah diperoleh serta mengevaluasi ide dan gagasan berdasarkan informasi, (3) memperbanyak latihan soal sehingga siswa banyak berlatih dalam mengekspresikan dan menuliskan ide yang mereka miliki menggunakan notasi matematika, (4) menayangkan video yang berkaitan dengan manfaat dari materi yang dipelajari untuk memotivasi siswa.
\end{abstract}

Kata kunci: POGIL, Kemampuan Komunikasi Matematis, Tanggapan.

\begin{abstract}
This study aims to determine: (1) improvement of students mathematical communication ability through the application of process oriented guided inquiry learning (POGIL), and (2) students responses to the application of POGIL. This type of research is a classroom action research conducted in three cycles. The subjects of this study were 26 students of class VII-1 in SMP Laboratorium Undiksha in the even semester of academic year 2017/2018. Data of students mathematical communication ability collected through test and data of student responses collected by questionnaires. The data that has been collected is analyzed descriptively. The results showed that the mean of student's mathematical communication score increases from 43.59 on initial reflection then continued to increase from cycle to cycle to 83.33 in cycle III. Students learning completeness also increases from $7.69 \%$ on initial reflection to $84.62 \%$ in cycle III and the mean of student's responses score has been in the positive category. The increase in each cycle occurs because the teacher places more emphasis on: (1) students actively extracting information by solving problems in exploration activities, (2) analyzing the information that already obtained and evaluating ideas based on information, (3) students practice more in expressing and writing their own ideas using mathematical notations, (4) showing videos related to the benefits of the material learned to motivate the students.
\end{abstract}

Keywords: POGIL, Mathematical Communication Ability, Response. 


\section{PENDAHULUAN}

Pendidikan merupakan hal penting bagi manusia karena proses dan hasil selama menempuh pendidikan dapat membantu dalam menghadapi pesatnya perkembangan ilmu pengetahuan dan teknologi. Pembelajaran di sekolah merupakan salah satu upaya formal dari pemerintah untuk meningkatkan kualitas pendidikan. Sekolah sebagai lembaga untuk kegiatan pembelajaran berfungsi untuk membelajarkan ilmu pengetahuan dan keterampilan kepada siswa. Sekolah membelajarkan berbagai bidang ilmu dan keahlian sesuai dengan tingkatan dan konsentrasi yang dipilih siswa. Adapun mata pelajaran yang selalu diperoleh siswa mulai dari jenjang dasar hingga perguruan tinggi adalah matematika.

Setiap sekolah memiliki permasalahan dalam pembelajaran matematika yang beragam. Salah satu sekolah yang memiliki permasalahan tersebut adalah SMP Laboratorium Undiksha. Sekolah ini merupakan salah satu sekolah yang baru mulai menerapkan kurikulum 2013 pada tahun ajaran 2017/2018. Sekolah belum sepenuhnya mampu menerapkan pendekatan dan model pembelajaran yang menjadi tuntutan kurikulum 2013. Hal ini menyebabkan sekolah senantiasa melalukan optimalisasi pembelajaran melalui berbagai cara. Peneliti melakukan observasi untuk mendiagnosa permasalahan pembelajaran matematika yang terjadi di kelas VII-1 SMP Laboratorium Undiksha. Berdasarkan hasil observasi awal yang dilakukan pada 27 November 2017, peneliti melakukan wawancara dengan guru mata pelajaran matematika kelas VII-1 yakni Si Luh Komang Purniati, S.Pd., adapun beberapa permasalahan yang diperoleh adalah sebagai berikut:

(1) Siswa belum mampu menyampaikan ide mereka secara matematis,

(2) Siswa merasa kurang yakin akan nilai kebenaran dari ide dan pendapat yang hendak mereka sampaikan,

(3) Siswa belum mampu mengkomunikasikan ide, gagasan, dan pendapat yang mereka miliki melalui simbol matematika, tabel, dan diagram yang tepat untuk memperjelas masalah dan keadaan.

Berdasarkan wawancara dengan 2 siswa kelas VII-1 SMP Laboratorium Undiksha, permasalahan ini disebabkan oleh siswa yang belum terbiasa berpikir secara sistematis. Siswa belum mampu menggunakan langkah prosedural karena pada jenjang sebelumnya mereka terbiasa menggunakan rumus cepat untuk menyelesaikan suatu permasalahan matematika. Siswa juga mengatakan bahwa mereka malu bertanya dan takut salah saat berpendapat di depan temantemannya. Berdasarkan wawancara, peneliti menduga bahwa permasalahan yang terjadi di kelas tersebut adalah kurangnya kemampuan komunikasi matematis siwa. Untuk lebih meyakinkan hal tersebut, peneliti melakukan tes awal yang terdiri dari 2 soal uraian. Hasil dari tes awal diperoleh bahwa hanya terdapat 2 siswa yang memperoleh nilai tes awal lebih dari kriteria ketuntasan minimal yang ditetapkan sekolah. Hasil tersebut menunjukkan bahwa kemampuan komunikasi matematis di kelas tersebut masih rendah. Oleh karena itu, komunikasi matematis siswa tersebut perlu mendapat perhatian dan jalan keluar yang tepat.

Pentingnya komunikasi matematis dalam dunia pendidikan matematika, maka pendidik tentu harus mengusahakan agar siswa mencapai hasil yang optimal dalam menguasai keterampilan komunikasi. Berbagai upaya dapat dilakukan, salah satu diantaranya dengan memberikan model pembelajaran yang sesuai bagi siswa. Pembelajaran konstruktivisme menekankan pada proses belajar, bukan mengajar. Peserta didik diberi kesempatan untuk membangun pengetahuan dan pemahaman baru yang didasarkan pada pengalaman yang nyata. Teori ini berpandangan bahwa belajar merupakan suatu proses, bukan menekankan hasil. Peserta didik didorong untuk melakukan penyelidikan dalam upaya mengembangkan rasa ingin tahu secara alami. Penilaian hasil belajar ditekankan pada kinerja dan pemahaman peserta didik (Sani, 2016:21).

Salah satu pembelajaran yang menganut paham konstruktivisme adalah 
pembelajaran inkuiri. Inquiry berasal dari kata to inquire yang berarti ikut serta atau terlibat dalam mengajukan pertanyaan, mencari informasi, dan melakukan penyelidikan. Model pembelajaran inkuiri bertujuan untuk memberikan cara bagi peserta didik untuk membangun kecakapan intelektual yang terkait dengan proses berpikir reflektif (Fathurrohman, 2015:104). Menurut Lott, kegiatan belajar secara inkuiri dapat dibedakan ke dalam beberapa kategori salah satunya adalah inkuiri terbimbing atau guided inquiry. Penggunaan inkuiri dalam pembelajaran di Arizona dibagi menjadi 3 fase dimana inkuiri terbimbing diterapkan kepada siswa kelas 4 sampai dengan kelas 8. Pada inkuiri terbimbing, permasalahan atau pertanyaan diajukan oleh guru. Guru membimbing peserta didik dalam melakukan penyelidikan. Peserta didik menentukan prosedur investigasi yang akan dilakukan. Guru membimbing peserta didik menganalisis data melalui diskusi (Sani, 2016:218).

Salah satu pengembangan dari model pembelajaran inkuiri terbimbing adalah Process Oriented Guided Inquiry Learning atau POGIL. POGIL merupakan suatu strategi instruksional yang memungkinkan guru mengajar materi dan keterampilan proses secara bersamaan. Selain itu, POGIL menekankan bahwa pembelajaran merupakan suatu proses interaktif dari berpikir, pendiskusian ide, penyempurnaan pemahaman, praktek keterampilan, refleksi kemajuan dan penilaian kinerja. POGIL biasanya digunakan terutama bagi peserta didik yang belum berpengalaman belajar dengan pendekatan inkuiri. Pada tahaptahap awal pengajaran diberikan bimbingan lebih banyak. Bimbingan tersebut berupa pertanyaan-pertanyaan pengarah agar peserta didik mampu menemukan sendiri arah dan tindakantindakan yang harus dilakukan untuk memecahkan permasalahan yang diberikan oleh guru. Pertanyaanpertanyaan pengarah selain dikemukakan langsung oleh guru juga diberikan melalui pertanyaan yang dibuat dalam lembar kerja peserta didik baik berupa LKS maupun modul. Oleh sebab itu, lembar kerja dibuat khusus untuk membimbing peserta didik dalam melakukan percobaan dan menarik kesimpulan.

Lembar kerja model pembelajaran inkuiri pada umumnya terdiri atas ilustrasi kemudian siswa merumuskan masalah secara mandiri, membuat hipotesis, melakukan eksperimen, dan menemukan konsep. Sedangkan lembar kerja siswa pada model pembelajaran POGIL terdiri atas 3 kegiatan. Kegiatan pertama adalah eksplorasi yang terdiri dari permasalahan untuk mengantarkan siswa menggali informasi lebih dalam terkait materi yang dipelajari. Kegiatan kedua adalah penemuan konsep yang memberikan kesempatan kepada siswa untuk menggeneralisasi hasil eksplorasinya menjadi sebuah konsep. Kegiatan ketiga adalah aplikasi konsep dimana siswa menggunakan konsep yang telah ditemukan untuk menyelesaikan soal aplikasi. Hal tersebut sesuai dengan pernyataan bahwa POGIL memiliki siklus pembelajaran yang berpusat pada siswa, model pembelajaran ini terdiri dari tiga fase, yaitu (1) eksplorasi, (2) penemuan konsep, dan (3) aplikasi (Warsono dkk, 2012).

Fase eksplorasi adalah fase penggalian dan perluasan pikiran siswa yang bertujuan untuk mengembangkan jalan pemikiran siswa. Siswa diajak untuk menggali informasi dengan cara membaca, berdiskusi, mengajukan pertanyaan, dan mengemukakan pendapat. Fase penemuan konsep dibangun dari pengetahuan sebelumnya dan pengetahuan baru yang diperoleh siswa selama fase eksplorasi. Siswa menggunakan pengalaman eksplorasinya untuk memperoleh kesimpulan berupa konsep utama dari materi yang dipelajari. Fase aplikasi konsep adalah fase dimana siswa menggunakan konsep yang telah ditemukan untuk menyelesaikan permasalahan baru. Hasil yang diperoleh dalam penyelesaian ini diuji kembali sebagai konfirmasi dari kebenaran konsep yang telah ditemukan. Pada fase aplikasi konsep diharapkan siswa mampu mengembangkan kemampuannya lebih dalam terkait penggunaan istilah dan notasi matematika untuk menyajikan ide. 
Ketiga fase dari model pembelajaran POGIL mengasah kemampuankemampuan siswa yakni: (a) kemampuan siswa dalam mengekspresikan ide, (b) kemampuan siswa untuk memahami, menginterpretasi, dan mengevaluasi ideide matematis, serta (b) kemampuan siswa dalam menggunakan istilah dan notasi matematika untuk menyajikan ide.

Beberapa penelitian sebelumnya yang mendukung penelitian ini adalah (1) penelitian yang dilakukan oleh Saputra pada tahun yang menyatakan bahwa penerapan model pembelajaran POGIL berbantuan GeoGebra dapat meningkatkan kemampuan pemahaman konsep matematika siswa kelas VII B4 SMP Negeri 6 Singaraja tahun ajaran 2016/2017 dan (2) penelitian yang dilakukan Aryanti pada tahun 2014 diperoleh bahwa kemampuan pemecahan masalah matematika siswa yang dibelajarkan dengan model pembelajaran POGIL lebih tinggi daripada kemampuan pemecahan masalah matematika siswa yang dibelajarkan dengan model pembelajaran konvensional. Relevansi dari keberhasilan model ini adalah model POGIL mampu meningkatkan kemampuan pemecahan masalah dimana siswa dituntut untuk menyusun dan mengintepretasi ide secara sistematis. Jika siswa mampu melakukan hal tersebut melalui penerapan model POGIL maka siswa juga akan mampu mengkomunikasikan idenya secara matematis.

Adapun tujuan dari penelitian ini adalah untuk mengetahui (1) Model pembelajaran POGIL dapat meningkatkan kemampuan komunikasi matematis siswa kelas VII-1 SMP Laboratorium Undiksha dan (2) Tanggapan siswa kelas VII-1 SMP Laboratorium Undiksha terhadap penerapan model pembelajaran POGIL.

\section{METODE}

Penelitian yang akan dilaksanakan adalah penelitian tindakan kelas kolaboratif yang secara umum bertujuan meningkatkan dan memperbaiki kualitas, proses, dan hasil pembelajaran matematika di kelas. Penelitian ini dilaksanakan dalam 3 (tiga) siklus. Dalam penelitian ini, PTK yang digunakan adalah model Kurt Lewin. Menurut Kurt Lewin (dalam Lewin dalam Sanjaya, 2013) setiap siklus terdiri atas 4 (empat) tahap yaitu perencanaan tindakan, pelaksanaan tindakan, observasi dan evaluasi serta refleksi dan pelaku pembelajaran dalam penelitian ini yaitu guru matematika kelas VII-1 SMP Laboratorium Undiksha. Selain itu sebelum pelaksanaan tindakan dilakukan simulasi terkait model pembelajaran yang akan digunakan. Data kemampuan komunikasi matematis dan tanggapan siswa dikumpulkan kemudian dianalisis menggunakan teknik analisis deskriptif.

\section{HASIL DAN PEMBAHASAN HASIL \\ Hasil Refleksi Awal}

Siswa kelas VII-1 SMP Laboratorium Undiksha diberikan tes awal berupa soal uraian pada tahap refleksi awal. Tes awal diberikan untuk memperoleh gambaran yang lebih jelas mengenai permasalahan dalam pembelajaran matematika yang terjadi di kelas tersebut. Hal ini merupakan tindak lanjut dari hasil wawancara dengan guru dan dua orang siswa seperti yang dipaparkan pada latar belakang. Hasil dari tes awal kemudian digunakan sebagai pertimbangan untuk menentukan anggota kelompok belajar yang heterogen.

Hasil analisis data kemampuan komunikasi matematis yang dimiliki siswa sebelum pelaksanaan tindakan memperlihatkan bahwa nilai terendah adalah 16,67 dan nilai tertinggi adalah 77,78 . Persentase banyaknya siswa yang nilai tes awalnya belum tuntas adalah $92,31 \%$ yaitu 24 orang, sedangkan persentase banyaknya siswa yang nilai tes awalnya sudah tuntas adalah $7,69 \%$ yaitu 2 orang Sebaran ketuntasan hasil tes awal kemampuan komunikasi matematis siswa sebelum pelaksanaan tindakan penelitian disajikan dalam Gambar 1.1 pada halaman berikut 


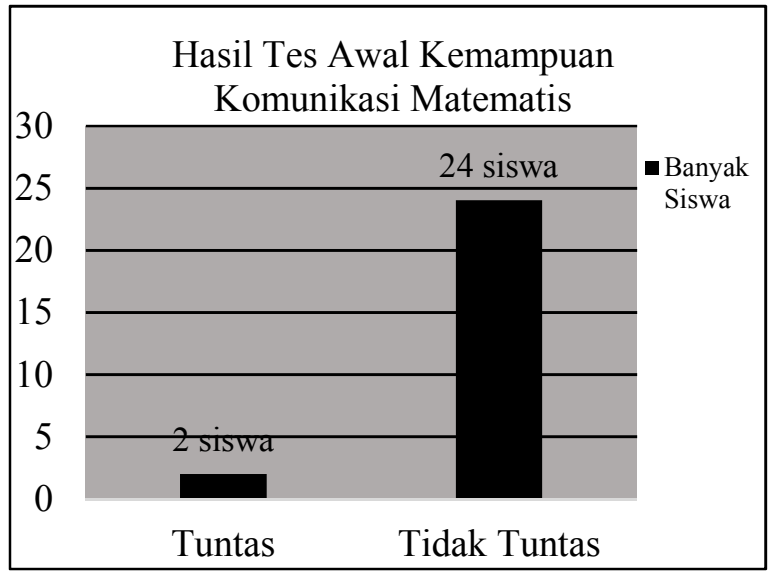

Gambar 1.1 Hasil Tes Awal Kemampuan Komunikasi Matematis

Berdasarkan hasil tes awal, ketuntasan belajar siswa secara klasikal adalah 7,69\%. Jumlah total nilai komunikasi matematis yang dimiliki siswa adalah 1133,33 dengan banyaknya siswa adalah 26 orang, sehingga rata-rata nilai komunikasi matematis yang dimiliki siswa adalah 43,59. Dengan demikian, rata-rata nilai komunikasi matematis yang dimiliki siswa kelas VII-1 SMP Laboratorium Undiksha belum memenuhi kriteria ketuntasan minimal yang telah ditetapkan.

\section{Hasil Penelitian Siklus I}

Pada akhir siklus I siswa diberikan tes hasil belajar yang terdiri dari lima soal uraian (essay). Dari analisis data tersebut diperoleh rata-rata nilai komunikasi matematis siswa adalah 57,37 dan ketuntasan belajar siswa secara klasikal adalah $42,31 \%$, yaitu hanya 11 siswa dari 26 siswa yang telah mampu mencapai KKM. Adapun sebaran data mengenai kemampuan komunikasi matematis siswa dapat diperhatikan pada Gambar 1.2 sebagai berikut

Gambar 1.2

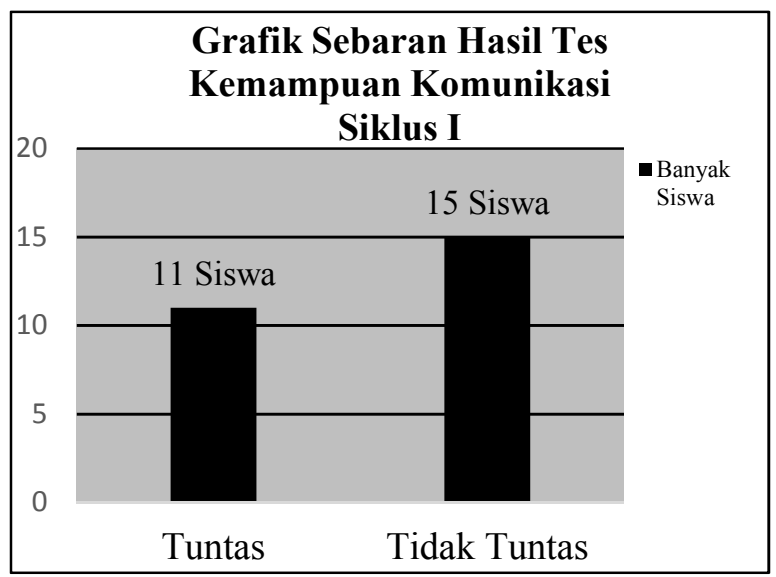

Grafik Sebaran Hasil Tes Kemampuan Komunikasi Matematis Siswa pada Siklus I

Berdasarkan gambar di atas, dapat disimpulkan bahwa rata-rata nilai tes kemampuan komunikasi matematis untuk materi arimatika sosial (keuntungan dan kerugian) yang dimiliki siswa kelas VII-1 SMP Laboratorium Undiksha pada siklus I belum memenuhi kriteria keberhasilan minimal yang telah ditetapkan. Ketuntasan belajar siswa secara klasikal juga belum memenuhi kriteria yang telah ditetapkan. Namun, rata-rata nilai komunikasi matematis yang dimiliki siswa dan ketuntasan belajar siswa sudah mengalami peningkatan dari refleksi awal ke siklus I.

\section{Hasil Penelitian Siklus II}


Pada akhir siklus II siswa diberikan tes hasil belajar yang terdiri dari lima soal uraian (essay). Dari analisis data tersebut diperoleh rata-rata nilai komunikasi matematis siswa adalah 72,76 dan ketuntasan belajar siswa secara klasikal adalah $57,69 \%$ yaitu hanya 15 siswa dari
26 siswa yang telah mampu mencapai KKM.

Adapun sebaran data mengenai kemampuan komunikasi matematis siswa dapat diperhatikan pada Gambar 1.3 sebagai berikut.

Gambar 1.3

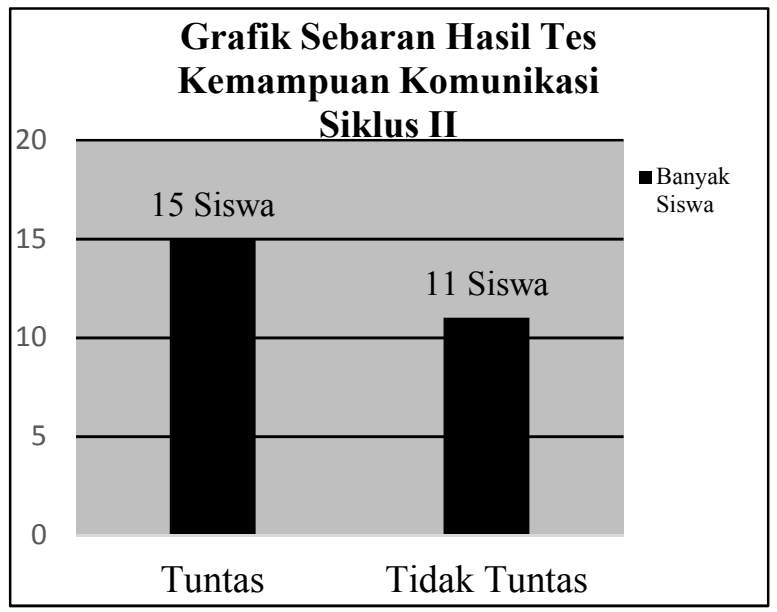

Grafik Sebaran Hasil Tes Kemampuan Komunikasi Matematis Siswa pada Siklus II

Berdasarkan gambar di atas, dapat disimpulkan bahwa rata-rata nilai tes kemampuan komunikasi matematis untuk materi arimatika sosial (bunga tunggal, pajak, potongan harga, bruto, neto, dan tara) yang dimiliki siswa kelas VII-1 SMP Laboratorium Undiksha pada siklus II belum memenuhi kriteria keberhasilan minimal yang telah ditetapkan. Ketuntasan belajar siswa secara klasikal belum memenuhi kriteria yang telah ditetapkan yaitu $70 \%$. Walaupun ketuntasan belajar siswa secara klasikal belum memenuhi kriteria yang telah ditetapkan oleh sekolah, tetapi rata-rata nilai kemampuan komunikasi matematis yang dimiliki siswa dan ketuntasan belajar siswa itu sendiri sudah mengalami peningkatan dari siklus I ke siklus II.

\section{Hasil Penelitian Siklus III}

Pada akhir siklus III siswa diberikan tes hasil belajar yang terdiri dari lima soal uraian (essay). Dari analisis data tersebut diperoleh rata-rata nilai komunikasi matematis siswa adalah 83,33 dan ketuntasan belajar siswa secara klasikal adalah $84,62 \%$ yaitu sebanyak 22 siswa dari 26 siswa yang telah mampu mencapai KKM.

Adapun sebaran data mengenai kemampuan komunikasi matematis siswa dapat diperhatikan pada Gambar 1.4 pada halaman berikut. 


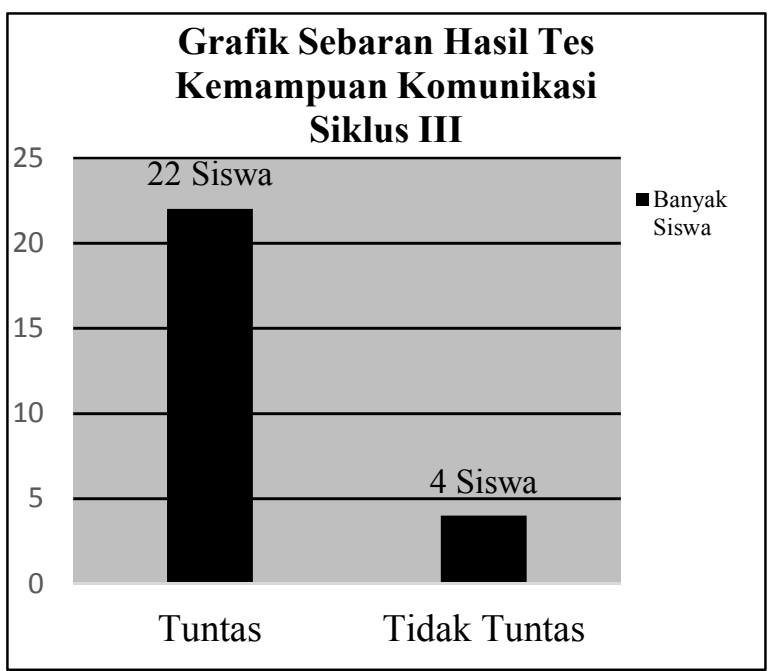

Gambar 1.4

Grafik Sebaran Hasil Tes Kemampuan Komunikasi Matematis Siswa pada Siklus III

Berdasarkan analisis data di atas, dapat disimpulkan bahwa rata-rata nilai komunikasi matematis yang dimiliki siswa pada materi garis dan sudut di kelas VII-1 SMP Laboratorium Undiksha pada siklus III sudah memenuhi kriteria keberhasilan minimal yang telah ditetapkan serta mengalami peningkatan dari siklus II.

\section{Peningkatan Komunikasi Matematis Siswa}

Peningkatan nilai rata-rata komunikasi matematis siswa pada tahap refleksi awal, siklus I, siklus II, dan siklus III dapat disajikan dalam Gambar 1.5 berikut.

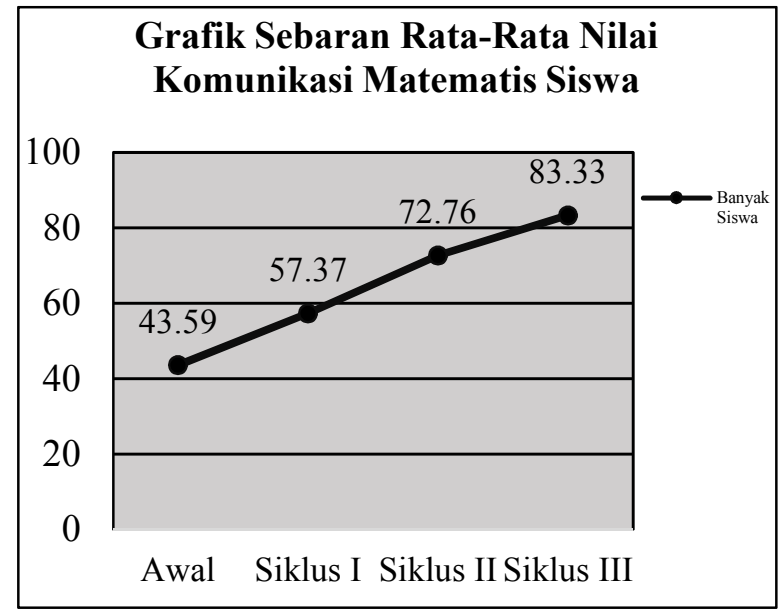

Gambar 1.5

Grafik Sebaran Nilai Rata-Rata Kemampuan Komunikasi Matematis Siswa

Adapun peningkatan ketuntasan belajar siswa secara klasikal pada tahap refleksi awal, siklus I, siklus II, dan siklus III dapat disajikan dalam Gambar 1.6 pada halaman berikut 


\section{Grafik Sebaran Ketuntasan Belajar Sisw:a}

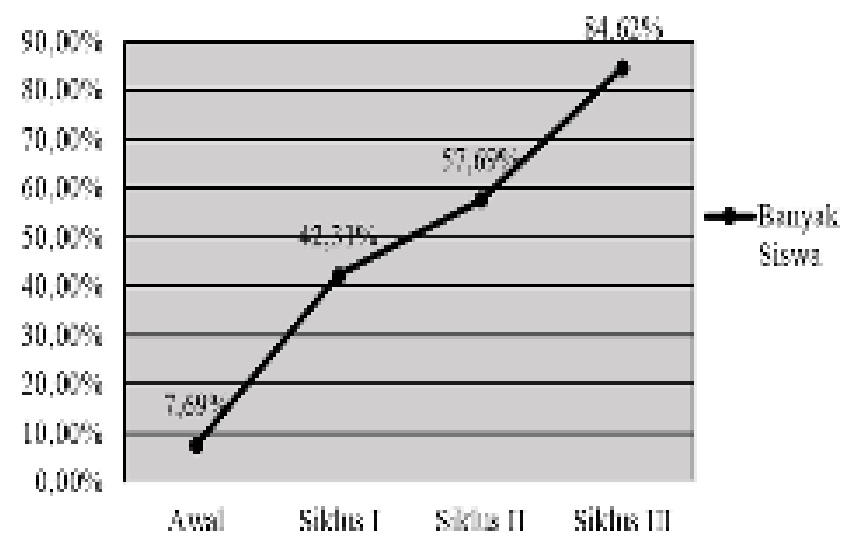

Gambar 1.6 Grafik Sebaran Ketuntasan Belajar Siswa

\section{Tanggapan Siswa}

Pada akhir pertemuan siklus III, siswa juga diberikan angket untuk mengetahui tanggapan siswa terhadap penerapan model pembelajaran POGIL. Data mengenai tanggapan siswa terhadap penerapan POGIL dikumpulkan pada akhir siklus III dengan menggunakan angket tanggapan siswa yang terdiri dari 15 butir pernyataan. Dari hasil analisis data terlihat bahwa skor tertinggi adalah 75 dan skor terendah adalah 53. Rata-rata skor tanggapan siswa terhadap penerapan POGIL selama proses pembelajaran adalah 61,16.

Sebaran data mengenai tanggapan siswa terhadap penerapan model pembelajaran POGIL disajikan pada Gambar 1.7 berikut.

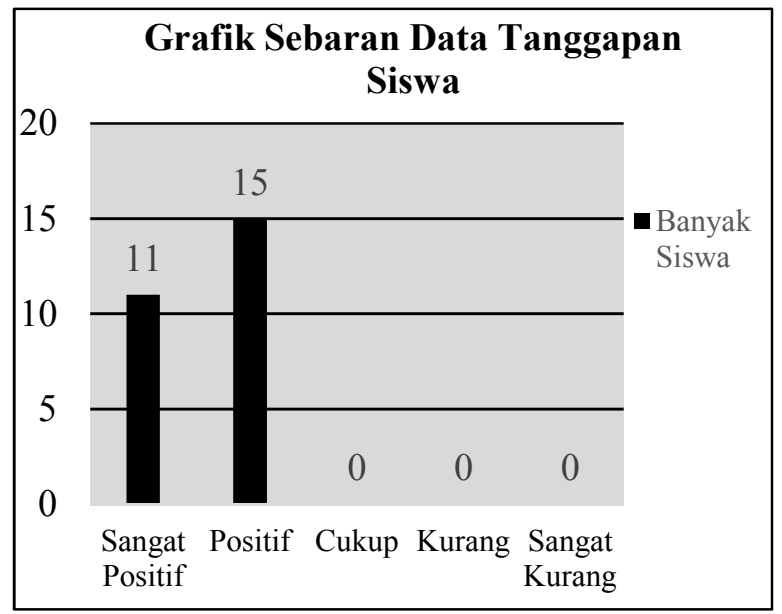

Gambar 1.7 Sebaran Data Tanggapan Siswa

Berdasarkan rata-rata skor tanggapan siswa terhadap penerapan POGIL selama proses pembelajaran, dapat disimpulkan bahwa pembelajaran melalui penerapan POGIL mendapatkan tanggapan yang positif dari siswa sesuai dengan kriteria penggolongan tanggapan siswa, sehingga tanggapan siswa terhadap penerapan POGIL selama proses pembelajaran sudah memenuhi kriteria indikator keberhasilan.

\section{PEMBAHASAN}

Berdasarkan penelitian yang telah dilaksanakan selama 3 siklus telah menunjukkan tercapainya peningkatan kemampuan komunikasi matematis yang dimiliki siswa kelas VII-1 SMP Laboratorium Undiksha melalui penerapan 
model pembelajaran POGIL. Hal ini terlihat dari hasil dan refleksi yang telah dipaparkan sebelumnya pada deskripsi kegiatan setiap siklus. Adapun hal-hal yang menyebabkan terjadinya peningkatan komunikasi matematis yang dimiliki siswa adalah sebagai berikut.

Pertama, pada tahap eksplorasi siswa dilatih agar menggali informasi pada buku paket dan berdiskusi dalam kelompok untuk menyelesaikan permasalahan yang diberikan pada LKS. Hal ini membuat siswa yang pada awalnya hanya mengandalkan guru dalam memperoleh informasi semakin mandiri dalam melakukan eksplorasinya sendiri. Diskusi dalam kelompok memotivasi siswa untuk lebih berani mengemukakan pendapatnya dalam kelompok kecil. Selain pertukaran ide untuk mampu menyelesaikan permasalahan, hal ini akan melatih siswa untuk mampu menyampaikan ide mereka dengan baik. Siswa berlatih menyampaikan ide agar dapat dipahami oleh teman dalam kelompoknya. Pembelajaran berlangsung lebih bermakna karena siswa dapat mengeksplorasi pengetahuan dan membangun pemahaman sesuai dengan pengalaman yang dimilikinya.

Kedua, pada tahap penemuan konsep, siswa dalam kelompoknya mengaitkan informasi yang telah diperoleh dan menentukan konsep yang ditemukan berdasarkan informasi tersebut. Guru memastikan setiap kelompok bersungguhsungguh dalam melaksanakan diskusi dan tidak hanya mengandalkan satu orang. Siswa diberikan kesempatan untuk berlatih menuliskan konsep matematika dengan bahasa sendiri. Setiap siswa harus siap untuk mempresentasikan hasil diskusinya. Guru mengarahkan perwakilan kelompok untuk memaparkan hasil kerja kelompoknya, hal ini memotivasi siswa untuk berani berpendapat dan mampu menuliskan ide mereka secara matematis. Pada akhir tahap penemuan konsep, guru menekankan hal-hal penting dari konsep yang dibahas.

Ketiga, guru memperbanyak latihan soal pada tahap aplikasi konsep sehingga siswa banyak berlatih dalam menuliskan ide yang mereka miliki. Siswa akan mampu mengkomunikasikan ide matematis dengan baik apabila secara kontinu berlatih melalui latihan soal. Hal ini akan memperkuat kemampuan komunikasi matematis siswa apabila telah terbiasa menuliskan penyelesaian secara matematis. Selama proses pembelajaran guru lebih menekankan pada pengekspresian ide-ide matematis. Hal ini dilakukan dengan memberikan pertanyaan pengarah bagi siswa yang mengalami kesulitan sehingga siswa akan membangun logika berpikirnya secara mendiri dan mampu mengkomunikasikan idenya secara matematis

Keempat, guru menayangkan video yang berkaitan dengan manfaat dari materi yang dipelajari pada siklus II dan III. Hal ini dilakukan untuk membuat siswa termotivasi selama mengikuti pembelajaran. Perbaikan yang dilakukan oleh guru selama proses pembelajaran dari siklus I, siklus II dan siklus III membuat siswa mampu mengemukakan ide-ide matematis yang mereka miliki. Hal ini berakibat pada siklus III pembelajaran telah berlangsung lebih baik dan memperoleh hasil sesuai dengan yang diharapkan. Penelitian yang sejalan dengan hal ini adalah penelitian yang dilakukan oleh Saputra (2017) menyatakan bahwa penerapan model pembelajaran POGIL berbantuan GeoGebra dapat meningkatkan kemampuan pemahaman konsep matematika siswa kelas VII B4 SMP Negeri 6 Singaraja tahun ajaran 2016/2017. Berdasarkan penelitian yang dilakukan diperoleh bahwa terjadi peningkatan pemahaman konsep siswa melalui penerapan model pembelajaran POGIL. Jika siswa telah memahami konsep matematika secara utuh maka siswa akan mampu mengkomunikasikan ide matematika dengan tepat. Penelitian yang dilakukan Aryanti (2014) diperoleh bahwa kemampuan pemecahan masalah matematika siswa yang dibelajarkan dengan model pembelajaran POGIL lebih tinggi daripada kemampuan pemecahan masalah matematika siswa yang dibelajarkan dengan model pembelajaran konvensional. Sehingga dapat disimpulkan bahwa model pembelajaran POGIL efektif dalam meningkatkan kemampuan 
pemecahan masalah matematika siswa. Relevansi dari keberhasilan model ini adalah model POGIL mampu meningkatkan kemampuan pemecahan masalah dimana siswa dituntut untuk menyusun dan mengintepretasi ide-ide secara sistematis. Jika siswa mampu melakukan hal tersebut melalui penerapan model POGIL maka siswa akan mampu mengkomunikasikan idenya secara sistematis pula. Selain terjadi peningkatan komunikasi matematis yang dimiliki siswa, penerapan POGIL dalam pembelajaran matematika juga mendapatkan respon positif dari siswa.

\section{SIMPULAN DAN SARAN Simpulan}

Berdasarkan hasil penelitian dan pembahasan yang telah dipaparkan pada bab sebelumnya, dapat disimpulkan beberapa hal sebaga berikut. Penerapan model pembelajaran Process Oriented Guided Inquiry Learning dapat meningkatkan kemampuan komunikasi siswa kelas VII-1 SMP Laboratorium Undiksha tahun ajaran 2017/2018. Hal ini dapat dilihat dari ketuntasan belajar siswa yang telah meningkat dari siklus ke siklus dan mencapai indikator keberhasilan yang ditetapkan. Ketuntasan belajar siswa pada siklus I, siklus II, dan siklus III berturut-turut yaitu $\quad 38,46 \%, \quad 57,69 \%, \quad 84,62 \%$. Peningkatan tersebut terjadi selama pelaksanaan pembelajaran pada setiap siklus. Pada siklus I, siswa masih belum mampu melakukan eksplorasi secara mandiri dan bertanya kepada guru untuk menyelesaikan permasalahan. Meskipun begitu terdapat beberapa siswa pula yang mampu melakukan eksplorasi secara mandiri untuk menemukan konsep maupun menyelesaikan permasalahan. Pada siklus II, siswa sudah terbiasa melakukan eksplorasi secara mandiri dan menemukan konsep. Meskipun diskusi kelompok hanya didominasi oleh beberapa siswa dan beberapa pendapat yang disampaikan siswa kurang tepat, siswa telah menunjukkan peningkatan karena telah berani berpendapat dan mempresentasikan idenya. Pada siklus III, siswa sudah terbiasa dengan pembelajaran yang diterapkan yakni melakukan eksplorasi, menemukan konsep, dan mengaplikasikan konsep. Guru memperbanyak latihan soal sehingga siswa terlatih untuk menuliskan idenya secara matematis. Meskipun beberapa pendapat siswa masih kurang tepat, siswa terlihat antusias dan terlibat aktif dalam diskusi dan mempresentasikan hasil kerjanya sehingga berdampak pada meningkatnya kemampuan komunikasi matematis siswa.

Tanggapan siswa kelas VII-1 SMP Laboratorium Undiksha terhadap penerapan model pembelajaran Process Oriented Guided Inquiry Learning ditinjau dari rata-rata skor angket tanggapan siswa berada pada kategori positif dengan ratarata sebesar 61,16 .

\section{Saran}

Berdasarkan temuan-temuan yang diperoleh selama melaksanakan penelitian ini, dapat diajukan beberapa saran sebagai berikut. Bagi guru yang mengalami permasalahan terkait rendahnya kemampuan komunikasi matematika siswa dapat menerapkan model pembelajaran Process Oriented Guided Inquiry Learning sebagai salah satu alternatif dalam menyelesaikan permasalahan tersebut. Guru matematika yang mengalami permasalahan serupa dapat mencoba menerapkan model pembelajaran ini pada pokok bahasan yang lain.

Bagi pembaca yang tertarik untuk melakukan penelitian lebih lanjut mengenai penerapan model pembelajaran Process Oriented Guided Inquiry Learning agar memperhatikan kendala-kendala yang dialami peneliti selama pelaksanaan penelitian sebagai pertimbangan untuk perbaikan, penyempurnaan, dan optimalisasi pelaksanaan penelitian.

\section{DAFTAR PUSTAKA}

Aryanti, R. 2014. Pengaruh Model Pembelajaran POGIL (Process Oriented Guided Inquiry Learning) Terhadap Kemampuan Pemecahan Masalah Matematika Siswa Kelas VIII SMP Negeri 6 Singaraja. Skripsi (tidak diterbitkan). Jurusan Pendidikan Matematika Undiksha. 
Barthlow, M. J. 2011. The Effectiveness of Process Oriented Guided Inquiry Learning to Reduce Alternate Conceptions in Secondary Chemistry. Disertasi Liberty University.

Fathurrohman, M. 2015. Model-model Pembelajaran Inovatif. Yogyakarta: Ar-Ruzz Media.

NCTM. 2000a. Principles and standards for teaching school mathematics. Reston. VA: Author.

Sani, R. A. 2016. Inovasi Pembelajaran. Jakarta: Bumi Aksara.

Sanjaya, W. 2013. Penelitian Tindakan Kelas. Jakarta: Prenadamedia Group.

Saputra, M. E. B. 2017. Penerapan model pembelajaran POGIL berbantuan GeoGebra untuk meningkatkan kemampuan pemahaman konsep matematika siswa kelas VII B4 SMP Negeri 6 Singaraja tahun ajaran 2016/2017. Skripsi (tidak diterbitkan). Jurusan Pendidikan Matematika Undiksha.

Sumarmo, U. 2016. Penilaian terhadap Nilai, Karakter, Budaya, dan Aspek Afektif Lain serta Pelaksanaan Pembelajaran Matematika. STKIP Siliwangi Bandung.

Warsono, dkk. 2012. Pembelajaran Aktif dan Teori Assesmen. Surabaya: Rosda

Wiriaatmadja, R. 2009. Metode Penelitian Tindakan Kelas. Bandung: PT Remaja Rosdakarya. 